\title{
LIME AND GYPSUM APPLICATION ON THE WHEAT CROP
}

\author{
Eduardo Fávero Caires ${ }^{1,4 *}$; Itacir Cesar Feldhaus²,3; Gabriel Barth²; Fernando José Garbuio² \\ ${ }^{1}$ Depto. de Ciência do Solo e Engenharia Agrícola - UEPG - Campus de Uvaranas, Av. General Carlos Cavalcanti $n^{\circ}$ \\ 4748 - CEP: 84030-900 - Ponta Grossa, PR. \\ ${ }^{2}$ Graduando em Agronomia - UEPG. \\ ${ }^{3} \mathrm{PIBIC/CNPq}$ Fellow. \\ ${ }^{4} \mathrm{CNPq}$ Fellow. \\ *Corresponding author <efcaires@uepg.br>
}

\begin{abstract}
Root growth and crop yield can be affected by chemical modifications of the soil profile owing to lime and gypsum applications. A field trial was carried out on a dystrophic Clayey Rhodic Hapludox at Ponta Grossa, PR, Brazil, aiming to evaluate lime (without or with incorporation into the soil) and gypsum effects on root growth, mineral nutrition and grain yield of wheat (cv. OR 1). A randomized complete block design was used, with three replications, in a split-plot experiment. Treatments with dolomitic limestone (without lime and $4.5 \mathrm{t} \mathrm{ha}^{-1}$ of lime applied on the surface, in total rate and $1 / 3$ of the requirement per year during 3 years, or incorporated into the soil) were applied in July 1998 (main plots) and the rates of gypsum $\left(0,3,6\right.$ and 9 t ha $\left.^{-1}\right)$ in October 1998 (subplots). Wheat was evaluated in the 2000 winter season. In conditions of water deficit absence, there was no limitation in root growth in depth, for exchangeable $\mathrm{Ca}$ of $6 \mathrm{mmol}_{\mathrm{c}} \mathrm{dm}^{-3}$. Lime incorporation of lime increased the $\mathrm{Mg}$ concentration in the leaves, but wheat yield was not influenced by the correction of soil acidity through liming treatments. Gypsum increased the concentrations of $\mathrm{Ca}$ and $\mathrm{S}$ in wheat leaves, with

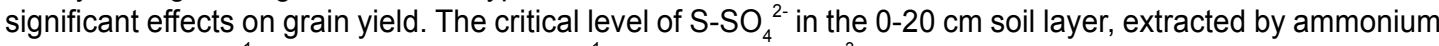
acetate $0.5 \mathrm{~mol} \mathrm{~L}^{-1}$ in acetic acid $0.25 \mathrm{~mol} \mathrm{~L}^{-1}$, was $25.8 \mathrm{mg} \mathrm{dm}^{-3}$.
\end{abstract}

Key words: Triticum aestivum L., root growth, calcium, sulphur, no-tillage system

\section{APLICAÇÃO DE CALCÁRIO E GESSO NA CULTURA DO TRIGO}

\begin{abstract}
RESUMO: A calagem e a aplicação de gesso levam a modificações químicas no perfil do solo que podem influenciar o crescimento radicular e a produção de culturas anuais. Um experimento foi realizado em Latossolo Vermelho distrófico textura argilosa, em Ponta Grossa (PR), com o objetivo de avaliar os efeitos da calagem (sem calcário e 4,5 t ha-1 de calcário dolomítico aplicado na superfície, em dose total e 1/3 da dose por ano durante 3 anos, e incorporado) e de doses de gesso na superfície $\left(0,3,6\right.$ e $\left.9 \mathrm{t} \mathrm{ha}^{-1}\right)$ sobre o crescimento radicular, a nutrição mineral e a produção de grãos de trigo (cv. OR 1). O delineamento experimental empregado foi em blocos ao acaso com parcelas subdivididas, com três repetições. Os tratamentos com calcário (parcelas) foram aplicados em julho, e as doses de gesso (subparcelas) em outubro de 1998. A cultura do trigo foi avaliada no inverno de 2000. Em condições de ausência de déficit hídrico, não houve limitação no crescimento radicular do trigo, em profundidade, para teor de Ca trocável de $6 \mathrm{mmol}_{\mathrm{c}} \mathrm{dm}^{-3}$. A incorporação de calcário aumentou a concentração de $\mathrm{Mg}$ nas folhas, mas a produção de grãos de trigo não foi influenciada pela correção da acidez do solo através da calagem na superfície, com ou sem parcelamento, ou com incorporação. A aplicação de gesso aumentou a concentração foliar de Ca e $S$, causando acréscimos na produção de grãos. O nível crítico de S-SO ${ }_{4}^{2-}$ no solo, na camada de $0-20 \mathrm{~cm}$, extraído pelo acetato de amônio $0,5 \mathrm{~mol} \mathrm{~L}^{-1} \mathrm{em}^{-1}$ ácido acético $0,25 \mathrm{~mol} \mathrm{~L}^{-1}$, foi de $25,8 \mathrm{mg} \mathrm{dm}^{-3}$.
\end{abstract}

Palavras-chave: Triticum aestivum L., crescimento radicular, cálcio, enxofre, sistema plantio direto

\section{INTRODUCTION}

Under no-tillage management, considerable increases in organic carbon and nitrogen concentrations occur, mainly in the surface layers of the soil, as a result of plant residue deposition and absence of disturbance (Anghinoni \& Salet, 1998). Recent reports have shown high crop yields, in the absence of liming, in acidic soils under this system (Caires et al., 1998; 1999; Pöttker \& Ben, 1998). The explanations for this have been associated to decreased aluminum toxicity (Salet et al., 1996), sufficient availability of exchangeable calcium and magnesium (Caires et al., 1998), and adequate nutrient uptake by the crops, probably as a result of higher soil water availability in the soil (Caires \& Fonseca, 2000).
In recent years, there has been increasing interest in finding alternative ways to establish crops under no-tillage in new areas, without soil disturbance. The benefits of this practice are related to the maintenance of the chemical and structural traits of the soil, increased erosion control, and economy in the operations of lime incorporation and tillage. However, if soil acidity is not adequately corrected, root growth and plant nutrition may be compromised.

Agricultural yield limitation caused by subsoil acidity, resulting from restraints to root growth and water and nutrient uptake by the crops have been widely reported in the literature (Pavan et al., 1982; Ritchey et al., 1982; Sumner et al., 1986; Farina \& Channon, 1988). 
When gypsum, which is relatively soluble (Bolan et al., 1991 cited by Sumner, 1995), is applied to a topsoil with acid subsoil, leaching occurs under the influence of an excess of moisture. Consequently, there is an increase in calcium supply and a decline in aluminum toxicity in the subsoil (Sumner, 1995). The positive effects of gypsum observed in the most diverse soil and weather conditions (Pavan et al., 1984; Sumner et al., 1986; Farina \& Channon, 1988; Raij et al., 1998) indicate that its utilization can also be a good alternative for the amelioration of the subsoil root environment in no-tillage management systems. Doubts remain, however, as to the conditions in which favorable effects of the gypsum on crop yield can be expected, probably as a result of the complex changes in the soil chemical attributes that derive from its application.

The present work was carried out with the aim of evaluating root growth, mineral nutrition and wheat grain yield in relation to changes in soil chemical traits brought about by surface liming at full or split rates, and incorporated lime, and by the application of gypsum rates, in no-tillage systems.

\section{MATERIAL AND METHODS}

The experiment was carried out in Ponta Grossa, PR, Brazil, Regina Farm, on a dystrophic Clay Rhodic Hapludox, used before as pastureland. At the beginning of the experiment, soil chemical (Pavan et al., 1992) and granulometric (EMBRAPA, 1997) analyses of the $0-20 \mathrm{~cm}$ layer showed the following results: $\mathrm{pH}$ (1:2.5 soil:0.01 mol L-1 $\mathrm{CaCl}_{2}$ suspension) 4.6; $78 \mathrm{mmol}_{\mathrm{c}} \mathrm{dm}^{-3}$ of $\mathrm{H}^{+}+\mathrm{Al}^{3+}$; $3 \mathrm{mmol} \mathrm{dm}$ of $\mathrm{Al}^{3+} ; 25 \mathrm{mmol} \mathrm{dm}^{-3}$ of $\mathrm{Ca}^{2+} ; 20 \mathrm{mmol}^{-3}$ $\mathrm{dm}^{-3}$ of $\mathrm{Mg}^{2+}$; $3.6 \mathrm{mmol}^{\mathrm{c}} \mathrm{dm}^{-3}$ of $\mathrm{K}^{+} ; 0.3 \mathrm{mg} \mathrm{dm}^{-3}$ of $\mathrm{P}^{\mathrm{c}}$ (Mehlich-1); $31 \mathrm{~g} \mathrm{dm}^{-3}$ of organic carbon, and $38 \%$ of base saturation, and clay, silt and sand contents of 580 , 130 and $290 \mathrm{~g} \mathrm{~kg}^{-1}$, respectively. The subsoil $(40-60 \mathrm{~cm})$ had $6 \mathrm{mmol}_{\mathrm{c}} \mathrm{dm}^{-3}$ of $\mathrm{Ca}^{2+}, 8 \mathrm{mmol}_{\mathrm{c}} \mathrm{dm}^{-3}$ of $\mathrm{Al}^{3+}$ and 620 $\mathrm{g} \mathrm{kg}^{-1}$ of clay.

A randomized complete block design was used, with three replications in the experiment with a split-plot arrangement. In the main plots, four treatments with dolomitic limestone with 89\% ECCE were applied: control (no lime); split application of lime on the surface (three yearly applications of $\left.1.5 \mathrm{t} \mathrm{ha}^{-1}\right)$; lime on the surface (4.5 $\left.\mathrm{t} \mathrm{ha}{ }^{-1}\right)$ and incorporated lime $\left(4.5 \mathrm{tha}^{-1}\right)$. The lime rate utilized was estimated by the soil base saturation method at $70 \%$, in the $0-20 \mathrm{~cm}$ layer. In the subplots, four different rates of gypsum (byproduct of the phosphoric acid industry) were surface-applied: $0,3,6$ and $9 \mathrm{t} \mathrm{ha}^{-1}$. Dolomitic limestone and gypsum were applied in July and October 1998, respectively. The incorporated lime treatment consisted of two separate operations. In one, half of the lime was surface broadcasted by hand and the soil plowed to the $20 \mathrm{~cm}$ depth with a disk plow. In the other part, the remaining half of the lime was added by hand on the surface, followed by plowing and immediately before harrowing with a disk harrow. In the treatment with annual splitting of surface-applied lime, the second application was conducted in May 1999, and the third, in May 2000. The areas of each plot and subplot were $224 \mathrm{~m}^{2}$ and $56 \mathrm{~m}^{2}$, respectively. The sequence of crops used was soybean (1998/1999), barley (1999), soybean (1999/2000) and wheat (2000). The present work addresses only the wheat crop, since the root growth and nutrition of this particular crop were studied more thoroughly.

Wheat, cv. OR 1, was sown on June 10th, 2000, at a seeding rate of 35 seeds $\mathrm{m}^{-1}$, and row spacing of 0.17 $\mathrm{m}$. Fertilizers were applied at rates of $330 \mathrm{~kg} \mathrm{ha}^{-1}$ of $10-$ 20-20 ( $\left.\mathrm{N}-\mathrm{P}_{2} \mathrm{O}_{5}-\mathrm{K}_{2} \mathrm{O}\right)$ in the sowing, and $100 \mathrm{~kg} \mathrm{ha}^{-1}$ of $\mathrm{N}$ as urea in top dressing.

Soil samples were taken prior to wheat sowing, corresponding to 23 months after liming and 20 months after gypsum application. Rainfall in the period between lime and gypsum application and soil sampling was 2915 and $2285 \mathrm{~mm}$, respectively. Twelve soil core samples per subplot were taken by means of a soil probe sampler to form a composite sample of the $0-5,5-10$ and $10-20 \mathrm{~cm}$ layers, and five cores of the 20-40, 40-60 and $60-80 \mathrm{~cm}$ layers. The $\mathrm{pH}$ and $\mathrm{H}^{+}+\mathrm{Al}^{3+}$ (total acidity $\mathrm{pH} 7.0$ ), $\mathrm{Al}^{3+}$, $\mathrm{Ca}^{2+}, \mathrm{Mg}^{2+}$ and $\mathrm{K}^{+}$concentrations were determined according to Pavan et al. (1992). Analyses of $\mathrm{S}^{-\mathrm{SO}_{4}}{ }^{2-}$ for the different soil depths were also performed through extraction by ammonium acetate $0.5 \mathrm{~mol} \mathrm{~L}^{-1}$ in acetic acid $0.25 \mathrm{~mol} \mathrm{~L}^{-1}$ and later determination by the turbidimetric method described by Vitti \& Suzuki (1978).

At the beginning of flowering, leaves were collected from 30 plants of each subplot, when the first to fourth leaf from the apices of the plants were collected. These samples were washed in de-ionized water, dried in a forced-air oven at $60^{\circ} \mathrm{C}$ until constant weight was achieved, and ground. The concentrations of $\mathrm{N}, \mathrm{P}, \mathrm{K}, \mathrm{Ca}$, $\mathrm{Mg}$, and $\mathrm{S}$ were analyzed through the methods described by Malavolta et al. (1997). At that same time, root samples were also collected by means of a sampling tube at four depths $(0-10,10-20,20-40$, and $40-60 \mathrm{~cm})$, when 6 sub-samples were taken, 3 from the sowing row and 3 between rows, to form a composite sample. The samples, with a diameter of $3.5 \mathrm{~cm}$, were randomly selected in only five treatments of lime $(L)$ and gypsum $(G)$ : control $\left(L_{0} L_{0}\right)$, gypsum $\left(L_{0} G_{9}\right)$, lime on the surface $\left(L_{4,5 \text { sup }} G_{0}\right)$, lime on the surface + gypsum $\left(L_{4,5 \text { sup }} G_{9}\right)$ and incorporated lime $\left(L_{4,5 i n c} G_{0}\right)$. The roots were separated from the soil by dispersion in water through a $0.5 \mathrm{~mm}$ mesh sieve. Root length was estimated by the method of Tennant (1975) and the mean radius and root surface area according to Hallmark \& Barber (1984).

Throughout the development period of the wheat crop, there was no water limitation. Rainfall was 181,98 , 95, 250 and $283 \mathrm{~mm}$, respectively, in the months of June, July, August, September, and October 2000. However, there occurred severe persistent frosts at the start of the crop development, which resulted in intense tillering. 
After maturation, the wheat was harvested and threshed, when time grain yield was determined at 130 $\mathrm{g} \mathrm{kg}^{-1}$ humidity. The middle twenty rows for four meters in length were harvested from each subplot, while two meters of each border were discarded.

The results were submitted to variance and regression analyses. In the absence of a significant interaction lime vs gypsum on the variables studied, the effects of liming were compared by the Tukey test at $5 \%$ probability, and the effects of gypsum, through regression analyses by orthogonal polynomials, by the means of the observations. The criterion adopted for choosing the model was the magnitude of the significant coefficients of determination at $5 \%$ probability.

\section{RESULTS AND DISCUSSION}

The results of chemical analyses of soil samples collected 23 months after liming (Table 1) showed that surface-applied lime, at full or split rates, and incorporated, led to an increase of $\mathrm{pH}$ in $\mathrm{CaCl}_{2} 0.01 \mathrm{~mol} \mathrm{~L}^{-1}, \mathrm{Ca}$ and $\mathrm{Mg}$ concentrations and base saturation, and a decrease of $\mathrm{H}^{+}$ $+\mathrm{Al}^{3+}$ levels in the $0-5 \mathrm{~cm}$ layer. Soil base saturation obtained for the surface layer $(0-5 \mathrm{~cm})$, both with surfaceapplied and incorporated lime, was close to the estimated $(70 \%)$ for the sample collected to the depth of $0-20 \mathrm{~cm}$. These results are in line with those observed in other reports (Caires et al., 2000; Weirich Neto et al., 2000). In the 5-10 and 10-20 cm layers, a greater response of lime was achieved with its incorporation into the soil, although surface liming, at full or split rates, also presented, to a lower degree, beneficial effects in acidity correction.

Liming, regardless of the application method, did not affect acidity of subsoil layers (20-40, 40-60 and 60$80 \mathrm{~cm}$ ), even though lime, especially when incorporated, promoted downward movement of $\mathrm{Ca}$ and $\mathrm{Mg}$ to the deeper layers of the soil, causing an elevation in the base saturation in depth (Table 1). Despite the fact that such effects are beneficial to plant development, the movement of $\mathrm{Ca}$ and $\mathrm{Mg}$ is not a good parameter to assess the downward movement of lime in the soil. Farina (1993) cited by Sumner (1995) also observed appreciable movement of $\mathrm{Ca}$ and $\mathrm{Mg}$ with the application of lime without a significant decrease in total acidity $\mathrm{pH} 7.0$ of the subsoil. This downward movement of $\mathrm{Ca}$ and $\mathrm{Mg}$ from the lime to deeper layers may be related to the formation of hydrosoluble organic compounds present in the plant residue (Ziglio et al., 1999; Franchini et al., 1999) or derive from the use of nitrogen fertilizers (Pearson et al., 1962; Weir, 1975) associated to nitrification-dependent reactions.

The application of gypsum, after 20 months, did not influence soil acidity (Table 2), but caused a raise in $\mathrm{pH}$ in the subsurface layers $(40-60$ and $60-80 \mathrm{~cm})$. The increase in subsoil pH through the application of gypsum was also found in other reports (Sousa \& Ritchey, 1986; Caires et al., 1999). Such effect has been attributed to a displacement reaction, with the $\mathrm{SO}_{4}^{2-}$ displacing the $\mathrm{OH}^{-}$ of the surface of soil particles, involving hydrated oxides of Fe and Al (Reeve \& Sumner, 1972). There was a linear increase in exchangeable $\mathrm{Ca}$ concentrations as a function of the gypsum rates at the six depths studied. In addition to the downward movement of $\mathrm{Ca}$, the gypsum also promoted leaching of exchangeable $\mathrm{Mg}(0-20 \mathrm{~cm})$ and $\mathrm{K}(0-40 \mathrm{~cm})$, causing an elevation of the levels of these nutrients in the subsoil $(40-60$ and $60-80 \mathrm{~cm}$ ).

Since the leaching of exchangeable Mg has been a frequent response in the studies involving gypsum application (Carvalho et al., 1986; Syed-Omar \& Sumner, 1991; Oliveira \& Pavan, 1996), its utilization has not been recommended alone, but in association to liming. However, in the $0-5$ and $5-10 \mathrm{~cm}$ layers, there was a significant interaction between liming treatments and gypsum rates. According to the adjusted regression equations, the decline in exchangeable $\mathrm{Mg}$ levels at $0-5 \mathrm{~cm}$, for each ton of gypsum applied, were 1.0, 1.7, 2.0 and $2.2 \mathrm{mmol}_{\mathrm{c}} \mathrm{dm}^{-3}$, respectively, for the treatments without lime, split-rate lime on the surface, full-rate lime on the surface and incorporated lime. In the $5-10 \mathrm{~cm}$ layer, the decline of exchangeable $\mathrm{Mg}$ caused by gypsum only occurred with liming. This decrease was around $1.5 \mathrm{mmol}_{\mathrm{c}} \mathrm{dm}^{-3}$ (surfaceapplied lime at split rates), $1.6 \mathrm{mmol}_{\mathrm{c}} \mathrm{dm}^{-3}$ (surface-applied lime at full rate) and $1.7 \mathrm{mmol}_{\mathrm{c}} \mathrm{dm}^{-3^{\mathrm{c}}}$ (incorporated lime) of $\mathrm{Mg}^{2+}$, per ton of gypsum. The downward movement of $\mathrm{Mg}^{2+}$ is more significant with greater concentrations of the nutrient in the soil, in agreement with those results obtained by Caires et al. (1998).

The leaching of exchangeable $\mathrm{K}$ which took place with the application of gypsum rates was not influenced by liming and was not very intense either, despite the high levels of $\mathrm{K}^{+}$in the soil (Table 2). The mean decreases in the concentrations of exchangeable $\mathrm{K}$, for each ton of gypsum applied, were $0.08,0.05,0.07$ and $0.06 \mathrm{mmol}_{\mathrm{c}}$ $\mathrm{dm}^{-3}$, respectively, at the depths of $0-5,5-10,10-20$ and $20-40 \mathrm{~cm}$. The increase in exchangeable $\mathrm{K}$ in the subsoil layers (40-60 and 60-80 cm) was around $0.06 \mathrm{mmol}_{\mathrm{c}} \mathrm{dm}^{-3}$ per ton of gypsum. Even though exchangeable $\mathrm{K}$ leaching as a result of the use of gypsum may occur depending on the soil type (Sousa \& Ritchey, 1986; Sumner, 1995), $\mathrm{K}^{+}$losses by leaching under a no-tillage system, as a consequence of gypsum application, have been of small magnitude (Caires et al., 1998).

The increase in soil base saturation obtained with the application of gypsum rates $(0-5,20-40,40-60$ and $60-80 \mathrm{~cm}$ ) derived from the increase in exchangeable calcium, having no relation to acidity correction (Table 2 ). This effect is clearly observed through the absence of the gypsum effect on the soil total acidity $\mathrm{pH} 7.0$.

The levels of $\mathrm{S}_{-} \mathrm{SO}_{4}{ }^{2-}$ at the various depths were not significantly influenced by lime applied on the surface, with or without splitting, or incorporated. The mean concentrations of S-SO ${ }_{4}^{2-}$, in $\mathrm{mg} \mathrm{dm}^{-3}$, were $16.6(0-5 \mathrm{~cm})$, $13.0(5-10$ and $10-20 \mathrm{~cm}), 14.0(20-40 \mathrm{~cm}), 9.0(40-60$ $\mathrm{cm})$ and $5.2(60-80 \mathrm{~cm})$. 
The application of gypsum rates raised $\mathrm{S}-\mathrm{SO}_{4}{ }^{2-}$ concentrations in the six depths (Figure 1). The mean increase in those concentrations per ton of gypsum were $9.7,10.6,14.2,16.8,19.0$ and 8.9 $\mathrm{mg} \mathrm{dm}{ }^{-3}$, respectively, at the depths of $0-5,5-10,10$ $20,20-40,40-60$ and $60-80 \mathrm{~cm}$. Therefore, there was a consistent increase in sulfate levels in the soil as a function of gypsum rates; the greatest accumulation occurred for the $40-60 \mathrm{~cm}$ depth after 20 months.

The gypsum $\mathrm{S}_{-} \mathrm{SO}_{4}{ }^{2-}$ was distributed uniformly throughout the soil profile instead of accumulating in one layer, which is in agreement with the results obtained by Sousa \& Ritchey (1986). The rate at which sulfate moves downward is variable for different soils (Quaggio et al.,
1993; Caires et al., 1998) and must be slower in soils richer in clay.

The attributes of wheat root growth were little affected by lime and gypsum (Table 3 ). Lime, when incorporated into the soil, promoted roots with smaller mean radius at the $10-20 \mathrm{~cm}$ depth, as compared to the absence of liming and gypsum application. This shows that the correction of soil acidity with the incorporation of lime favors the formation of thinner roots in this soil layer. Nevertheless, root density and surface area of wheat were not significantly influenced by liming and/or gypsum treatments.

The wheat crop showed $67 \%$ of root length in the 0-20 cm layer, regardless of liming, surface applied or incorporated, and gypsum application. Approximately 33\%

Table 1 - Changes in soil chemical traits for different depths, 23 months after the application of liming treatments.

\begin{tabular}{|c|c|c|c|c|c|c|}
\hline \multirow[t]{2}{*}{ Treatment } & \multirow{2}{*}{$\begin{array}{l}\mathrm{pH} \text { in } \\
\mathrm{CaCl}_{2}\end{array}$} & \multirow{2}{*}{$\mathrm{H}^{+}+\mathrm{Al}^{3+}$} & \multicolumn{3}{|c|}{ Exchangeable Cations } & \multirow{2}{*}{$\begin{array}{c}\text { Base } \\
\text { Saturation }\end{array}$} \\
\hline & & & $\mathrm{Ca}^{2+}$ & $\mathrm{Mg}^{2+}$ & $\mathrm{K}^{+}$ & \\
\hline & \multicolumn{5}{|c|}{ - - } & $\%$ \\
\hline & \multicolumn{6}{|c|}{$0-5 \mathrm{~cm}$} \\
\hline No lime & 4.8 & 80.6 & 53 & 17 & 6.7 & 49 \\
\hline Surface-applied lime ${ }^{(1)}$ & 5.5 & 52.3 & 67 & 28 & 6.9 & 66 \\
\hline Surface-applied lime ${ }^{(2)}$ & 5.7 & 49.2 & 72 & 29 & 6.7 & 69 \\
\hline Incorporated lime & 5.6 & 44.6 & 63 & 26 & 7.2 & 68 \\
\hline $\operatorname{LSD}(P=0.05)$ & 0.3 & 8.2 & 13.6 & 8.4 & 1.7 & 5.8 \\
\hline \multirow[t]{2}{*}{$\mathrm{CV}(\%)$} & 4.3 & 10.3 & 15.1 & 23.4 & 17.7 & 6.5 \\
\hline & \multicolumn{6}{|c|}{$5-10 \mathrm{~cm}$} \\
\hline No lime & 4.7 & 77.8 & 38 & 15 & 5.1 & 43 \\
\hline Surface-applied lime ${ }^{(1)}$ & 5.1 & 61.8 & 44 & 24 & 5.0 & 54 \\
\hline Surface-applied lime (2) & 5.1 & 62.9 & 43 & 23 & 4.4 & 53 \\
\hline Incorporated lime & 5.5 & 48.6 & 53 & 26 & 4.8 & 63 \\
\hline $\operatorname{LSD}(P=0.05)$ & 0.3 & 10.1 & 6.9 & 12.7 & 1.4 & 8.3 \\
\hline \multirow[t]{2}{*}{ CV (\%) } & 4.9 & 11.3 & 10.9 & 41.3 & 20.5 & 11.0 \\
\hline & \multicolumn{6}{|c|}{$10-20 \mathrm{~cm}$} \\
\hline No lime & 4.5 & 82.2 & 27 & 14 & 3.6 & 35 \\
\hline Surface-applied lime (1) & 4.8 & 70.4 & 32 & 19 & 3.5 & 44 \\
\hline Surface-applied lime (2) & 4.8 & 69.8 & 32 & 18 & 2.9 & 43 \\
\hline Incorporated lime & 5.1 & 58.2 & 38 & 24 & 3.2 & 53 \\
\hline $\operatorname{LSD}(P=0.05)$ & 0.2 & 8.9 & 7.8 & 7.4 & 1.3 & 8.6 \\
\hline \multirow[t]{2}{*}{$\mathrm{CV}(\%)$} & 3.5 & 9.0 & 16.9 & 27.4 & 28.9 & 13.9 \\
\hline & \multicolumn{6}{|c|}{$20-40 \mathrm{~cm}$} \\
\hline No lime & 4.5 & 82.5 & 16 & 12 & 2.4 & 27 \\
\hline Surface-applied lime ${ }^{(1)}$ & 4.5 & 79.1 & 19 & 14 & 2.3 & 31 \\
\hline Surface-applied lime ${ }^{(2)}$ & 4.6 & 77.8 & 21 & 13 & 1.8 & 32 \\
\hline Incorporated lime & 4.7 & 70.3 & 22 & 17 & 2.1 & 37 \\
\hline $\operatorname{LSD}(P=0.05)$ & 0.2 & 18.1 & 4.7 & 4.8 & 0.7 & 7.2 \\
\hline \multirow[t]{2}{*}{ CV $(\%)$} & 3.7 & 16.6 & 17.4 & 23.9 & 23.4 & 16.1 \\
\hline & \multicolumn{6}{|c|}{$40-60 \mathrm{~cm}$} \\
\hline No lime & 4.5 & 74.9 & 11 & 10 & 1.9 & 23 \\
\hline Surface-applied lime ${ }^{(1)}$ & 4.6 & 73.2 & 11 & 10 & 2.2 & 24 \\
\hline Surface-applied lime ${ }^{(2)}$ & 4.6 & 68.6 & 14 & 12 & 1.4 & 29 \\
\hline Incorporated lime & 4.7 & 67.1 & 17 & 14 & 2.2 & 33 \\
\hline $\operatorname{LSD}(P=0.05)$ & 0.2 & 8.5 & 4.9 & 3.6 & 1.0 & 5.8 \\
\hline \multirow[t]{2}{*}{$\mathrm{CV}(\%)$} & 2.4 & 8.5 & 25.5 & 19.6 & 38.6 & 14.4 \\
\hline & \multicolumn{6}{|c|}{$60-80 \mathrm{~cm}$} \\
\hline No lime & 4.5 & 62.4 & 7 & 8 & 1.9 & 21 \\
\hline Surface-applied lime ${ }^{(1)}$ & 4.6 & 63.1 & 7 & 9 & 2.0 & 22 \\
\hline Surface-applied lime (2) & 4.7 & 60.8 & 9 & 9 & 1.4 & 24 \\
\hline Incorporated lime & 4.7 & 59.5 & 10 & 11 & 1.8 & 28 \\
\hline $\operatorname{LSD}(P=0.05)$ & 0.2 & 12.8 & 5.1 & 2.8 & 1.1 & 5.6 \\
\hline CV (\%) & 2.9 & 14.7 & 42.1 & 21.8 & 43.1 & 16.6 \\
\hline
\end{tabular}

(1) $1 / 3$ of the lime rate appplied per year on the surface for 3 years. ${ }^{(2)}$ full-rate lime on the surface in a single application. 
of the root length was concentrated in the subsoil $(20-60$ $\mathrm{cm})$. There was no water deficit during the crop cycle. Without water and nutrient restraints, the plant concentrates its roots in the layers where growth is easier, in order not to impair the absorption process (Marschner, 1986). The lack of response of the wheat root system to the increase in exchangeable $\mathrm{Ca}$ in the subsoil layers must be related to the low critical level values of the nutrient for root growth (Ritchey et al., 1982). Moreover, low concentrations of exchangeable Al were found in the subsoil layers ( 2 to $5 \mathrm{mmol}_{\mathrm{c}} \mathrm{dm}^{-3}$ ), despite the fact that the chemical analysis results obtained prior to the installation of the experiment revealed the presence of toxic $\mathrm{Al}$ (8 mmol $\mathrm{dm}^{-3}$ ). This decline in exchangeable $\mathrm{Al}$ in the subsoil is likely to have occurred naturally by the presence of plant residue kept on the soil surface. Recent research demonstrated a decrease in exchangeable $\mathrm{Al}$ in the soil caused by plant material, and this is related to the increase in $\mathrm{pH}$ and organic complexation (Miyazawa et al., 1993; Franchini et al., 1999).

Liming increased $\mathrm{Mg}$ concentration in wheat leaves only when lime was incorporated into the soil (Table 4), while the gypsum rates increased linearly leaf concentrations of $\mathrm{Ca}$ and S. Caires et al. (1999) also observed an increase in $\mathrm{Mg}$ concentration in wheat leaves with liming, but $\mathrm{Ca}$ leaf concentration increased only with the utilization of gypsum. The increase in the concentration of $S$ in wheat leaves brought by gypsum was significantly related $(P<0.01)$ to the increase in available $\mathrm{S}_{-} \mathrm{SO}_{4}^{2-}$ in the soil at the six depths studied: 0 -

Table 2 - Changes in soil chemical traits for different depths, 20 months after the application of gypsum rates.

\begin{tabular}{|c|c|c|c|c|c|c|}
\hline \multirow{2}{*}{ Treatment } & \multirow{2}{*}{$\begin{array}{l}\mathrm{pH} \mathrm{in} \\
\mathrm{CaCl}_{2}\end{array}$} & \multirow[b]{2}{*}{$\mathrm{H}^{+}+\mathrm{Al}^{3+}$} & \multicolumn{3}{|c|}{ Exchangeable Cations } & \multirow{2}{*}{$\begin{array}{c}\text { Base } \\
\text { Saturation }\end{array}$} \\
\hline & & & $\mathrm{Ca}^{2+}$ & $\mathrm{Mg}^{2+}$ & $\mathrm{K}^{+}$ & \\
\hline \multirow[t]{2}{*}{$\mathrm{tha}^{-1}$} & & 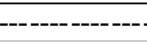 & 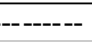 & $n^{-3}-\ldots$ & ---------- & $\%$ \\
\hline & \multicolumn{5}{|c|}{$0-5 \mathrm{~cm}$} & \\
\hline 0 & 5.4 & 59.2 & 49 & 33 & 7.3 & 60 \\
\hline 3 & 5.4 & 57.7 & 59 & 28 & 7.0 & 62 \\
\hline 6 & 5.4 & 55.7 & 67 & 23 & 6.6 & 63 \\
\hline 9 & 5.4 & 54.0 & 79 & 18 & 6.6 & 66 \\
\hline Effect & ns & ns & $L^{* *}$ & $\mathrm{~L}^{* *}$ & $L^{* *}$ & $L^{* *}$ \\
\hline \multirow[t]{2}{*}{$\mathrm{CV}(\%)$} & 2.4 & 13.9 & 9.6 & 16.3 & 9.2 & 6.3 \\
\hline & \multicolumn{6}{|c|}{$5-10 \mathrm{~cm}$} \\
\hline 0 & 5.1 & 62.3 & 34 & 28 & 5,0 & 52 \\
\hline 3 & 5.1 & 63.2 & 42 & 24 & 5,0 & 53 \\
\hline 6 & 5.1 & 63.8 & 48 & 19 & 4.7 & 53 \\
\hline 9 & 5.1 & 61.5 & 54 & 16 & 4.7 & 55 \\
\hline Effect & ns & ns & $L^{* *}$ & $L^{* *}$ & $L^{*}$ & ns \\
\hline \multirow[t]{2}{*}{ CV (\%) } & 3.3 & 11.4 & 11.1 & 16.6 & 10.8 & 7.9 \\
\hline & \multicolumn{6}{|c|}{$10-20 \mathrm{~cm}$} \\
\hline 0 & 4.8 & 69,0 & 25 & 23 & 3.5 & 43 \\
\hline 3 & 4.8 & 71.1 & 30 & 20 & 3.6 & 43 \\
\hline 6 & 4.8 & 72.2 & 35 & 17 & 3.2 & 43 \\
\hline 9 & 4.9 & 68.3 & 41 & 15 & 3.0 & 46 \\
\hline Effect & ns & ns & $L^{* *}$ & $L^{* *}$ & $L^{* *}$ & ns \\
\hline \multirow[t]{2}{*}{$\mathrm{CV}(\%)$} & 3.1 & 9.8 & 14.8 & 17.1 & 15.1 & 10.3 \\
\hline & \multicolumn{6}{|c|}{$20-40 \mathrm{~cm}$} \\
\hline 0 & 4.6 & 72.7 & 14 & 14 & 2.4 & 29 \\
\hline 3 & 4.6 & 78.7 & 16 & 15 & 2.1 & 30 \\
\hline 6 & 4.6 & 78.4 & 21 & 15 & 2.0 & 33 \\
\hline 9 & 4.6 & 80.0 & 26 & 13 & 1.9 & 34 \\
\hline Effect & ns & ns & $L^{* *}$ & ns & $L^{* *}$ & $L^{*}$ \\
\hline \multirow[t]{2}{*}{$\mathrm{CV}(\%)$} & 3.1 & 11.2 & 14.1 & 19.5 & 21.5 & 14.5 \\
\hline & \multicolumn{6}{|c|}{$40-60 \mathrm{~cm}$} \\
\hline 0 & 4.5 & 68.7 & 8 & 9 & 1.6 & 21 \\
\hline 3 & 4.6 & 71.8 & 12 & 12 & 1.8 & 26 \\
\hline 6 & 4.6 & 72.2 & 15 & 14 & 2.0 & 30 \\
\hline 9 & 4.7 & 71.1 & 19 & 16 & 2.1 & 34 \\
\hline Effect & $L^{* *}$ & ns & $L^{* *}$ & $\mathrm{~L}^{* *}$ & $L^{*}$ & $L^{* *}$ \\
\hline \multirow{2}{*}{$C \vee(\%)$} & 2.4 & 9.4 & 19.2 & 17.7 & 28.9 & 13.0 \\
\hline & \multicolumn{6}{|c|}{$60-80 \mathrm{~cm}$} \\
\hline 0 & 4.5 & 59.3 & 6 & 7 & 1.3 & 19 \\
\hline 3 & 4.6 & 62.0 & 7 & 8 & 1.8 & 21 \\
\hline 6 & 4.6 & 62.1 & 9 & 9 & 2.0 & 24 \\
\hline 9 & 4.7 & 62.3 & 12 & 11 & 1.9 & 29 \\
\hline Effect & $L^{* *}$ & ns & $L^{* *}$ & $\mathrm{~L}^{* *}$ & $\mathrm{~L}^{*}$ & $L^{* *}$ \\
\hline CV (\%) & 2.5 & 8.6 & 22.1 & 20.1 & 30.6 & 13.3 \\
\hline
\end{tabular}

$\mathrm{L}=$ linear effect by polynomial regression. $\mathrm{ns}=$ non-significant, ${ }^{*}=$ significant $\mathrm{P}<0.05,{ }^{*}=$ significant $\mathrm{P}<0.01$. 
$5 \mathrm{~cm}(r=0.66), 5-10 \mathrm{~cm}(r=0.69), 10-20 \mathrm{~cm}(r=0.73)$, $20-40 \mathrm{~cm}(r=0.72), 40-60 \mathrm{~cm}(r=0.76)$ and $60-80 \mathrm{~cm}$ $(r=0.64)$. The increases in $S$ leaf concentrations were directly related to the gains in availability of the nutrient in the soil, assessed through extraction with ammonium acetate $0.5 \mathrm{~mol} \mathrm{~L}^{-1}$ in acetic acid $0.25 \mathrm{~mol} \mathrm{~L}^{-1}$ (Figure 1 ).
Wheat grain yield was not significantly influenced by the liming treatments. The mean yields were 3685 , 3694,3695 and $3602 \mathrm{~kg} \mathrm{ha}^{-1}$, respectively, for the treatments without lime, split-rate lime on the surface, fullrate lime on the surface, and incorporated lime. These results are in agreement with those obtained in other

Table 3 - Wheat root growth traits for different soil depths as a function of lime and gypsum treatments.

\begin{tabular}{|c|c|c|c|c|}
\hline Treatment & $\begin{array}{c}\text { Root } \\
\text { Density }\end{array}$ & $\begin{array}{c}\text { Root } \\
\text { Surface }\end{array}$ & $\begin{array}{c}\text { Mean } \\
\text { Radius } \\
\end{array}$ & $\begin{array}{c}\text { Relative } \\
\text { Length }\end{array}$ \\
\hline & $\mathrm{cm} \mathrm{cm}^{-3}$ & $\mathrm{~cm}^{2} \mathrm{~cm}^{-3}$ & $\mathrm{~mm}$ & $\%$ \\
\hline & \multicolumn{4}{|c|}{$0-10 \mathrm{~cm}$} \\
\hline Control & 2.56 & 0.239 & 0.15 & 50 \\
\hline Surface-applied lime ${ }^{(1)}$ & 2.51 & 0.232 & 0.15 & 56 \\
\hline Gypsum (2) & 2.71 & 0.261 & 0.15 & 53 \\
\hline Surface-applied lime (1) + Gypsum (2) & 2.56 & 0.258 & 0.16 & 55 \\
\hline Incorporated lime & 2.62 & 0.241 & 0.15 & 55 \\
\hline $\operatorname{LSD}(P=0.05)$ & 2.31 & 0.225 & 0.04 & 19 \\
\hline \multirow[t]{2}{*}{$\mathrm{CV}(\%)$} & 31.6 & 32.4 & 8.7 & 13.0 \\
\hline & \multicolumn{4}{|c|}{$10-20 \mathrm{~cm}$} \\
\hline Control & 0.60 & 0.069 & 0.19 & 13 \\
\hline Surface-applied lime ${ }^{(1)}$ & 0.61 & 0.060 & 0.15 & 14 \\
\hline Gypsum (2) & 0.69 & 0.068 & 0.15 & 14 \\
\hline Surface-applied lime (1) + Gyp sum (2) & 0.54 & 0.054 & 0.16 & 12 \\
\hline Incorporated lime & 0.67 & 0.056 & 0.13 & 14 \\
\hline $\operatorname{LSD}(P=0.05)$ & 0.51 & 0.055 & 0.04 & 11 \\
\hline \multirow[t]{2}{*}{$\mathrm{CV}(\%)$} & 29.3 & 31.6 & 9.6 & 30.0 \\
\hline & \multicolumn{4}{|c|}{$20-40 \mathrm{~cm}$} \\
\hline Control & 0.54 & 0.049 & 0.14 & 21 \\
\hline Surface-applied lime ${ }^{(1)}$ & 0.37 & 0.034 & 0.15 & 17 \\
\hline Gypsum (2) & 0.49 & 0.045 & 0.15 & 18 \\
\hline Surface-applied lime (1) + Gyp sum (2) & 0.49 & 0.046 & 0.15 & 21 \\
\hline Incorporated lime & 0.32 & 0.029 & 0.14 & 14 \\
\hline $\operatorname{LSD}(P=0.05)$ & 0.36 & 0.034 & 0.03 & 8 \\
\hline \multirow[t]{2}{*}{$\mathrm{CV}(\%)$} & 29.2 & 29.9 & 7.6 & 15.6 \\
\hline & \multicolumn{4}{|c|}{$40-60 \mathrm{~cm}$} \\
\hline Control & 0.43 & 0.037 & 0.13 & 17 \\
\hline Surface-applied lime ${ }^{(1)}$ & 0.28 & 0.024 & 0.13 & 13 \\
\hline Gyp sum (2) & 0.40 & 0.038 & 0.14 & 15 \\
\hline Surface-applied lime (1) + Gyp sum (2) & 0.39 & 0.025 & 0.14 & 12 \\
\hline Incorporated lime & 0.40 & 0.034 & 0.13 & 18 \\
\hline $\operatorname{LSD}(P=0.05)$ & 0.36 & 0.037 & 0.04 & 13 \\
\hline CV $(\%)$ & 33.7 & 41.5 & 10.6 & 30.6 \\
\hline
\end{tabular}

(1) full-rate lime on the surface in a single application. (2) $9 \mathrm{t} \mathrm{ha}^{-1}$ of surface-applied gypsum.

Table 4 - Nutrient concentration in wheat leaves as a function of lime and gypsum rates.

\begin{tabular}{|c|c|c|c|c|c|c|}
\hline Treatment & $\mathrm{N}$ & $\mathrm{P}$ & $\mathrm{K}$ & $\mathrm{Ca}$ & $\mathrm{Mg}$ & $S$ \\
\hline & \multicolumn{5}{|c|}{ Liming } & - \\
\hline No lime & 37.4 & 2.3 & 20.8 & 4.6 & 1.7 & 3.8 \\
\hline Surface-applied lime (1) & 37.3 & 2.4 & 21.4 & 5.1 & 2.2 & 4.1 \\
\hline Surface-applied lime (2) & 38.2 & 2.3 & 20.6 & 5.0 & 2.0 & 3.6 \\
\hline Incorporated lime & 38.2 & 2.3 & 20.3 & 5.3 & 2.3 & 3.5 \\
\hline $\operatorname{LSD}(P=0.05)$ & 2.7 & 0.3 & 2.5 & 0.8 & 0.5 & 0.9 \\
\hline CV $(\%)$ & 5.0 & 8.2 & 8.7 & 11.9 & 20.3 & 18.2 \\
\hline \multicolumn{7}{|l|}{ Gypsum, t ha- ${ }^{-1}$} \\
\hline 0 & 37.6 & 2.3 & 20.6 & 4.1 & 2.1 & 3.0 \\
\hline 3 & 37.9 & 2.3 & 20.9 & 4.8 & 2.1 & 3.6 \\
\hline 6 & 38.2 & 2.4 & 20.8 & 5.2 & 2.2 & 4.0 \\
\hline 9 & 37.3 & 2.3 & 20.8 & 5.9 & 1.9 & 4.3 \\
\hline Effect & ns & ns & ns & $L^{* *}$ & ns & $L^{* *}$ \\
\hline CV $(\%)$ & 2.5 & 5.6 & 6.1 & 11.8 & 22.3 & 10.1 \\
\hline
\end{tabular}

(1) $1 / 3$ of the lime rate appplied per year on the surface for 3 years. ${ }^{(2)}$ full-rate lime on the surface in a single application. $L=$ linear effect by polynomial regression. $\mathrm{ns}=$ non-significant, ${ }^{* *}=$ significant $\mathrm{P}<0.01$. 
reports (Pöttker \& Ben, 1998; Caires et al., 1999) and show that, in the absence of water deficit, it is possible to achieve high wheat grain yield in acidic soils under a no-tillage system, provided that exchangeable $\mathrm{Ca}$ and $\mathrm{Mg}$ concentrations are sufficient and exchangeable Al levels are not toxic.

The application of gypsum rates increased wheat grain yield and the response was quadratic (Figure 2). According to the adjusted regression equation, the maximum wheat yield would be reached at a gypsum rate of $8.2 \mathrm{t} \mathrm{ha}^{-1}$, corresponding to a yield increase of $420 \mathrm{~kg}$ $\mathrm{ha}^{-1}$. Very similar results were obtained in another trial with the application of gypsum rates for corn (Caires et al., 1999).

The alterations that the application of gypsum to the soil brings about are complex and their effects on plants are difficult to be isolated. In soils with Al toxicity in the subsurface layers, the improvement in growth and the increase in wheat yield with the use of gypsum have been related to the increase in the concentration of sulfate in the subsoil solution, which causes an increase in ionic force and a decrease in $\mathrm{Al}^{3+}$ activity through the establishment of the ionic pair $\mathrm{AlSO}_{4}^{+}$(Mclay et al., 1994). Since in the present work Al levels were not very high, this effect must not have been the most relevant.

The positive and significant correlation $(P<0.05)$ between leaf concentrations of $S$ and wheat grain yield $(r=0,61)$ indicates that there was a response of wheat to the increase in soil S-SO ${ }_{4}^{2-}$ concentrations owing to the supply of sulfur by the gypsum. The relation between

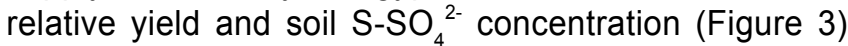
shows the positive effect of the elevation of available S-
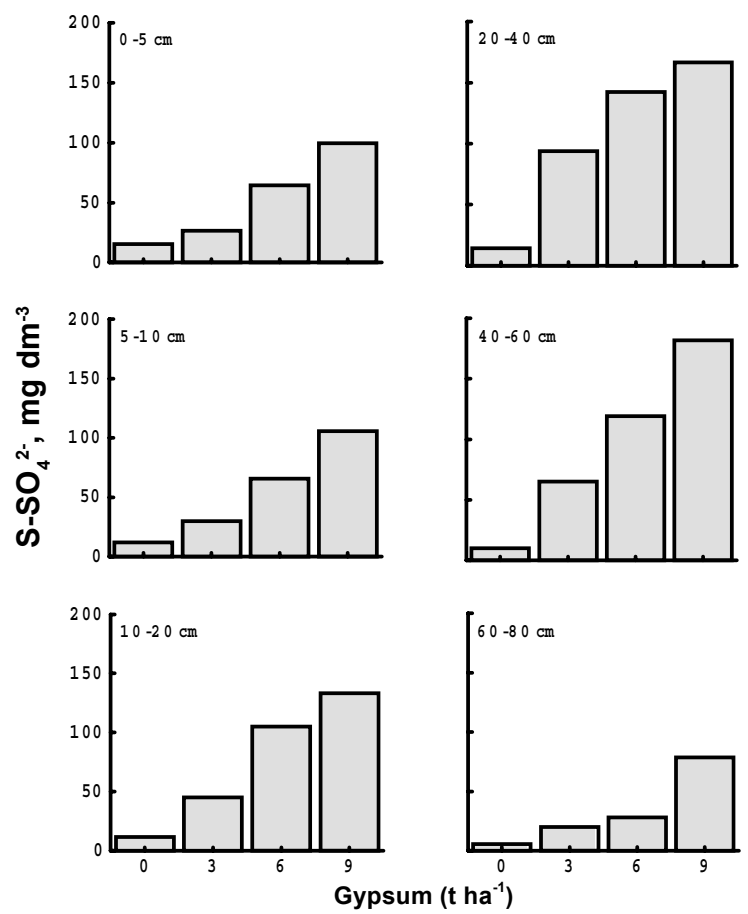

Figure 1 - Effect of gypsum rates, after 20 months, on soil S-SO ${ }_{4}{ }^{2-}$ levels, extracted by ammonium acetate $0.5 \mathrm{~mol} \mathrm{~L}^{-1}$ in acetic acid $0.25 \mathrm{~mol} \mathrm{~L}^{-1}$, for different depths.
$\mathrm{SO}_{4}^{2-}$ in the $0-20 \mathrm{~cm}$ layer caused by gypsum rates on wheat yield. The critical level of soil $\mathrm{S}_{-} \mathrm{SO}_{4}^{2-}$, extracted by ammonium acetate $0.5 \mathrm{~mol} \mathrm{~L}^{-1}$ in acetic acid $0.25 \mathrm{~mol}$ $\mathrm{L}^{-1}$, was $25.8 \mathrm{mg} \mathrm{dm}^{-3}$.

Many doubts still exist regarding the establishment of critical levels of $S$ in the soil. Concentrations of 10 to $15 \mathrm{mg} \mathrm{dm}^{-3} \mathrm{~S}_{-} \mathrm{SO}_{4}^{2-}$ for the extraction with ammonium acetate $0.5 \mathrm{~mol} \mathrm{~L}^{-4}$ in acetic acid $0.25 \mathrm{~mol} \mathrm{~L}^{-1}$ have been proposed as critical levels, considering results of studies conducted with several crops (Malavolta et al., 1987 cited by Vitti, 1989). However, in order to achieve high wheat grain yields, it is possible that the critical level of soil S-SO ${ }_{4}^{2-}$ could be higher. The importance of sulfate availability in the soil stands out, especially during the grain filling stage, considering that $S$ is relatively immobile in the plant (Eriksen et al., 2001).

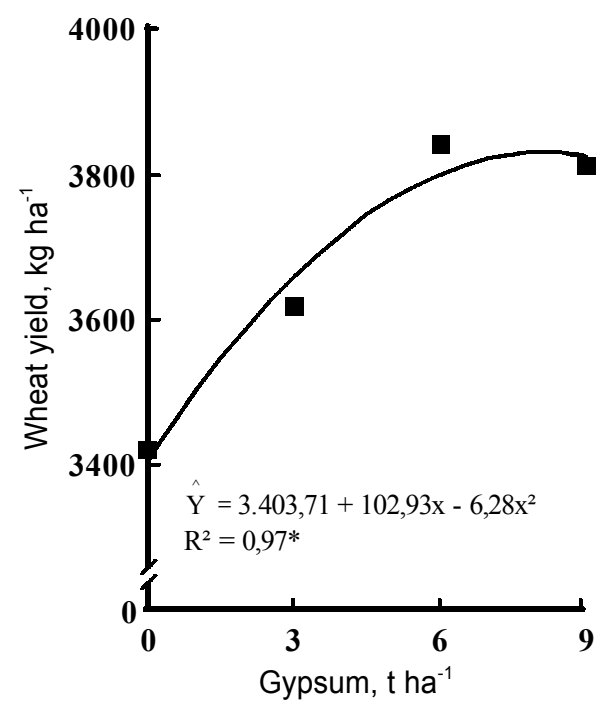

Figure 2 - Wheat grain yield as a function of gypsum rates applied on soil surface. ${ }^{*}=$ significant $P<0.05$.

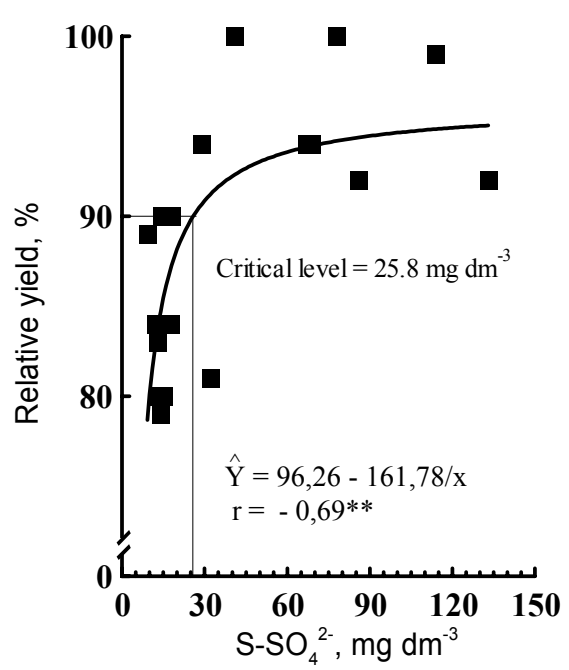

Figure 3 - Relation between relative wheat grain yield and soil S$\mathrm{SO}_{4}{ }^{2-}$ level, for the $0-20 \mathrm{~cm}$ layer, extracted by ammonium acetate $0.5 \mathrm{~mol} \mathrm{~L}^{-1}$ in acetic acid $0.25 \mathrm{~mol} \mathrm{~L}^{-1} .{ }^{* *}=$ significant $\mathrm{P}<0.01$. 
Wheat grain yield was also positively related $(P$ $<0.05)$ to the level of $\mathrm{Ca}(r=0.50)$ and $\mathrm{Ca} / \mathrm{Mg}$ ratio $(r=$ 0.52 ) in the leaves. The increase in $\mathrm{Ca}$ concentration in the solution reduces $\mathrm{Mg}$ concentration in the shoots, but not in the roots, while the increase in $\mathrm{Mg}$ concentration in the solution reduces $\mathrm{Ca}$ concentration in the wheat roots and shoots by effect of ionic competition (Wheeler \& Edmeades, 1995). Thus, the increase in exchangeable $\mathrm{Ca}$ and the movement of exchangeable $\mathrm{Mg}$ in the soil brought by gypsum application may have promoted $\mathrm{Ca}$ uptake by the plant, reflecting positively on wheat grain yield.

\section{REFERENCES}

ANGHINONI, I: SALET, R.L. Amostragem do solo e as recomendações de adubação e calagem no sistema plantio direto. In: NUERNBERG, N.J. (Ed.) Conceitos e fundamentos do sistema plantio direto. Lages: SBCS, Núcleo Regional Sul, 1998. p.27-52.

CAIRES, E.F.; CHUEIRI, W.A.; MADRUGA, E.F.; FIGUEIREDO, A. Alterações de características químicas do solo e resposta da soja ao calcário e gesso aplicados na superfície em sistema de cultivo sem preparo do solo. Revista Brasileira de Ciência do Solo, v.22, p.27-34, 1998.

CAIRES, E.F.; FONSECA, A.F.; MENDES, J.; CHUEIRI, W.A.; MADRUGA, E.F. Produção de milho, trigo e soja em função das alterações das características químicas do solo pela aplicação de calcário e gesso na superfície, em sistema de plantio direto. Revista Brasileira de Ciência do Solo, v.23, p.315-327, 1999

CAIRES, E.F.; BANZATTO, D.A.; FONSECA, A.F. Calagem na superfície em sistema plantio direto. Revista Brasileira de Ciência do Solo, v.24, p.161169, 2000.

CAIRES, E.F.; FONSECA, A.F. Absorção de nutrientes pela soja cultivada no sistema de plantio direto em função da calagem na superfície. Bragantia, v.59, p.213-220, 2000.

CARVALHO, L.J.C.B.; GOMIDE, R.L.; RODRIGUES, G.C.; SOUSA, D.M.G.; FREITAS Jr., E. Resposta do milho à aplicação de gesso e déficit hídrico em solos de cerrado. In: SEMINÁRIO SOBRE O USO DE FOSFOGESSO NA AGRICULTURA, 1., Brasília, 1986. Anais. Brasília: EMBRAPA, DDT, 1986. p.61-83.

EMPRESA BRASILEIRA DE PESQUISA AGROPECUÁRIA. Centro Nacional de Pesquisa de Solos. Manual de métodos de análise de solo. 2.ed. Rio de Janeiro: EMBRAPA, CNPS, 1997. 212p.

ERIKSEN, J.; NIELSEN, M.; MORTENSEN, J.V.; SCHJORRING, J.K. Redistribution of sulphur during generative growth of barley plants with different sulphur and nitrogen status. Plant and Soil, v.230, p.239-246, 2001.

FARINA, M.P.W.; CHANNON, P. Acid-subsoil amelioration. II. Gypsum effects on growth and subsoil chemical properties. Soil Science Society of America Journal, v.52, p.175-180, 1988.

FRANCHINI, J.C.; MALAVOLTA, E.; MIYAZAWA, M.; PAVAN, M.A. Alterações químicas em solos ácidos após a aplicação de resíduos vegetais. Revista Brasileira de Ciência do Solo, v.23, p.533-542, 1999.

HALLMARK, W.B.; BARBER, S.A. Root growth and morphology, nutrient uptake and nutrient status of early grown soybeans as affected by soil $P$ and K. Agronomy Journal, v.76, p.209-212, 1984.

MALAVOLTA, E.; VITTI, G.C.; OLIVEIRA, S.A. Avaliação do estado nutricional das plantas: princípios e aplicações. 2.ed. Piracicaba: Associação Brasileira para Pesquisa da Potassa e do Fosfato, 1997. 319p.

MARSCHNER, H. Mineral nutrition of higher plants. New York: Academic Press, 1986. 403p.

MCLAY, C.D.A.; RITCHIE, G.S.P.; PORTER, W.M.; CRUSE, A. Amelioration of subsurface acidity in sandy soils in low rainfall regions. 2 . Changes to soil solution composition following the surface application of gypsum and lime. Australian Journal of Soil Research, v.32, p.847-865, 1994.

MIYAZAWA, M.; PAVAN, M.A.; CALEGARI, A. Efeito de material vegetal na acidez do solo. Revista Brasileira de Ciência do Solo, v.17, p.411-416, 1993.
OLIVEIRA, E.L.; PAVAN, M.A. Control of soil acidity in no-tillage system for soybean production. Soil \& Tillage Research, v.38, p.47-57, 1996.

PAVAN, M.A.; BINGHAM, F.T.; PRATT, P.F. Toxicity of aluminum to coffee in Ultisols and Oxisols amended with $\mathrm{CaCO}_{3}$ and $\mathrm{CaSO}_{4}$. Soil Science Society of America Journal, v.46, p.1201-1207, 1982.

PAVAN, M.A.; BINGHAM, F.T.; PRATT, P.F. Redistribution of exchangeable calcium, magnesium and aluminum following lime and gypsum applications to a Brazilian Oxisol. Soil Science Society of America Journal, v.48, p.33-38, 1984.

PAVAN, M.A.; BLOCH, M.F.; ZEMPULSKI, H.C.; MIYAZAWA, M.; ZOCOLER, D.C. Manual de análise química do solo e controle de qualidade. Londrina: Instituto Agronômico do Paraná, 1992. 38p. (Circular, 76).

PEARSON, R.W.; ABRUNA, F.; VICENTE-CHANDLER, J. Effect of lime and nitrogen applications on downward movement of calcium and magnesium in two humid tropical soils of Puerto Rico. Soil Science, v.93, p.77-82, 1962.

PÖTTKER, D.; BEN, J.R. Calagem para uma rotação de culturas no sistema plantio direto. Revista Brasileira de Ciência do Solo, v.22, p.675-684, 1998.

QUAGGIO, J.A.; RAIJ, B. van; GALLO, P.B.; MASCARENHAS, H.A.A. Respostas da soja à aplicação de calcário e gesso e lixiviação de íons no perfil do solo. Pesquisa Agropecuária Brasileira, v.28, p.375-383, 1993.

RAIJ, B. van; FURLANI, P.R.; GUAGGIO, J.A.; PETTINELLI JR., A. Gesso na produção de cultivares de milho com tolerância diferencial a alumínio em três níveis de calagem. Revista Brasileira de Ciência do Solo, v.22, p.101-108, 1998.

REEVE, N.G.; SUMNER, M.E. Amelioration of subsoil acidity in Natal Oxisols by leaching of surface applied amendments. Agrochemophysica, v.4, p.1-6, 1972 .

RITCHEY, K.D.; SILVA, S.E.; COSTA, V.F. Calcium deficiency in clayey B horizons of savannah Oxisols. Soil Science, v.133, p.378-382, 1982.

SALET, R.L.; ANGHINONI, I.; FORNARI, T.G.; KRAY, C.H. O alumínio é menos tóxico no sistema plantio direto. In: REUNIÃO SUL-BRASILEIRA DE CIÊNCIA DO SOLO, 1., Lages, 1996. Resumos expandidos. Lages: SBCS, Núcleo Regional Sul, 1996. p.72-74.

SOUSA, D.M.G.; RITCHEY, K.D. Uso de gesso no solo de cerrado. In: SEMINÁRIO SOBRE O USO DE FOSFOGESSO NA AGRICULTURA, 1., Brasília, 1986. Anais. Brasília: EMBRAPA, DDT, 1986. p.119-144.

SUMNER, M.E. Amelioration of subsoil acidity with minimum disturbance. In: JAYAWARDANE, N.S.; STEWART, B.A. (Ed.) Subsoil management techniques. Athens: Lewis Publishers, 1995. p.147-185.

SUMNER, M.E.; SHAHANDEH, H.; BOUTON, J.; HAMMEL, J. Amelioration of an acid soil profile through deep liming an surface application of gypsum. Soil Science Society of America Journal, v.50, p.1254-1278, 1986.

SYED-OMAR, S.R.; SUMNER, M.E. Effect of gypsum on soil potassium and magnesium status and growth of alfafa. Communications in Soil Science and Plant Analysis, v.22, p.2017-2028, 1991.

TENNANT, D. A test of a modified line intersect method of estimating root length. Journal of Ecology, v.63, p.995-1001, 1975.

VITTI, G.C. Enxofre do solo. In: BÜLL, L.T.; ROSOLEM, C.A. (Ed.) Interpretação de análise química de solo e planta para fins de adubação. Botucatu: Fundação de Estudos e Pesquisas Agrícolas e Florestais, 1989. p.129-173.

VITTI, G.C.; SUZUKI, J.A. A determinação do enxofre - sulfato pelo método turbidimétrico. Jaboticabal: Universidade Estadual de São Paulo, 1978. 13p.

WEIR, C.C. Effect of lime and nitrogen application on citrus yields and on the downward movement of calcium and magnesium in a soil. Tropical Agriculture, v.51, p.230-234, 1975.

WEIRICH NETO, P.H.; CAIRES, E.F.; JUSTINO, A.; DIAS, J. Correção da acidez do solo em função de modos de incorporação de calcário. Ciência Rural, v.30, p.257-261, 2000.

WHEELER, D.M.; EDMEADES, D.C. Effect of varying solution calcium or magnesium concentrations in the presence or absence of aluminum on yield and plant calcium or magnesium concentrations in wheat. Journal of Plant Nutrition, v.18, p.2229-2245, 1995.

ZIGLIO, C.M.; MIYAZAWA, M.; PAVAN, M.A. Formas orgânicas e inorgânicas de mobilização do cálcio no solo. Brazilian Archives of Biology and Technology, v.42, p.257-262, 1999.

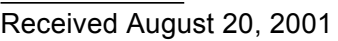

